\title{
Politicas Públicas no Atendimento À População Estrangeira no Sistema Público de Saúde na Região Metropolitana de São Paulo (RMSP) - Avanços e Perspectivas Futuras
}

\author{
Rufino, Catia \\ Prefeitura Municipal de São Paulo — catrufino@superig.com.br
}

INTRODUÇÃO: Esta pesquisa contextualiza a construção das políticas de saúde e da gestão do Sistema Único de Saúde (SUS) no que se refere à população estrangeira na Região Metropolitana de São Paulo (RMSP). OBJETIVO: Compreender como o acesso humanitário, universal e igualitário à saúde, garantida pela legislação brasileira, tem alcançado esta população e em quais condições os gestores e profissionais de saúde estão lidando com esta situação na RMSP. MÉTODO: Revisão de pesquisas científicas realizadas na área da saúde e políticas sociais, estudo das legislações e visitas a instituições que atuam no atendimento ao imigrante internacional. RESULTADOS: em 2012 houve uma intensificação da imigração internacional para o Brasil, com um crescimento de cerca de $50 \%$ em comparação ao ano de 2010, e a RMSP representou o principal destino destes imigrantes. Atender ao estrangeiro é um desafio para a saúde pública na RMSP, mas não se trata de criar uma nova demanda ao SUS, visto que esta já existe, mas sim reconhecê-la respeitando suas especificidades. no SUS surgiram inúmeros modelos de gestão pública visando à assistência à saúde, com diferentes formatos, mas que ainda não garantem aos brasileiros e aos estrangeiros, a universalidade, integralidade e equidade garantida em lei. no país, ainda não existem políticas públicas em saúde para atender aos imigrantes internacionais, apesar da vulnerabilidade desta população, e as unidades de saúde não estão preparadas para este atendimento. Somente em 2013, iniciou-se no município de São Paulo um processo de construção de políticas públicas direcionadas ao imigrante internacional, tendo como uma de suas metas o combate à xenofobia, o que contribui para um atendimento humanitário no serviço público de saúde. Esta iniciativa, apesar de incipiente, traz aos profissionais da saúde e de outras áreas, e à sociedade civil em geral, a necessidade de uma discussão acerca da diversidade étnica e cultural na busca da compreensão e respeito às populações estrangeiras no país. CONCLUSÕES: a atenção à saúde dos imigrantes internacionais na RMSP é um desafio que necessita ser reconhecido e compreendido pela sociedade brasileira, apesar da legislação do país garantir acesso universal à rede pública de saúde, direito de qualquer pessoa no território brasileiro, e também do SUS trazer como diretrizes a universalidade, integralidade e equidade no atendimento a toda população, incluindo os estrangeiros, de modo que na gestão pública da saúde sejam garantidos os direitos humanos fundamentais a esta população.

Rufino, Catia. Politicas Públicas no Atendimento À População Estrangeira no Sistema Público de Saúde na Região Metropolitana de São Paulo (Rmsp) - Avanços e Perspectivas Futuras. In: Anais do Congresso Internacional de Humanidades \& Humanização em Saúde [= Blucher Medical Proceedings, num.2, vol.1]. São Paulo: Editora Blucher, 2014. ISSN 2357-7282

DOI 10.5151/medpro-cihhs-10304 